\title{
Long-term impact after fulminant Guillain-Barré syndrome, case report and literature review
}

This article was published in the following Dove Press journal:

International Medical Case Reports Journal

7 November 2016

Number of times this article has been viewed

\author{
Alain Rougé $e^{1,2}$ \\ Jérémie Lemarié1,2 \\ Sébastien Gibot ${ }^{1,2}$ \\ Pierre Edouard Bollaert ${ }^{1,2}$ \\ 'Medical Intensive Care Unit, \\ Hôpital Central, University Hospital \\ of Nancy, Nancy, France; ${ }^{2}$ INSERM \\ UMRS-I I I6, Faculty of Medicine, \\ University of Lorraine, Nancy, France
}

Correspondance: Jérémie Lemarié Service de réanimation médicale, Hôpital Central, CHRU de Nancy, 29 Avenue du Maréchal de Lattre de Tassigny, 54000 Nancy, France

Email j.lemarie@chru-nancy.fr

\begin{abstract}
A 47-year-old man was admitted to the intensive care unit a few hours after presenting to emergency department with acute diplopia and dysphonia. Swallowing disorders and respiratory muscular weakness quickly required invasive ventilation. On day 3, the patient was in a "brain-death"-like state with deep coma and absent brainstem reflexes. Electroencephalogram ruled out brain death diagnosis as a paradoxical sleep trace was recorded. Cerebrospinal fluid analysis, electrophysiologic studies, and a recent history of diarrhea led to the diagnosis of Campylobacter jejuni-related fulminant Guillain-Barré syndrome (GBS) mimicking brain death. The outcome was favorable after long Intensive Care Unit and inpatient rehabilitation stays, despite persistent disability at 9 years follow-up. This case and the associated literature review of 34 previously reported fulminant GBS patients emphasize the importance of electrophysiological investigations during clinical brain-death states with no definite cause. Fulminant GBS has a worse outcome than "standard" GBS with higher rates of severe disability (about 50\%). Longterm physiotherapy and specific rehabilitation programs appear essential to improve recovery. Keywords: fulminant Guillain-Barré syndrome, brain death, electroencephalogram, C. jejuni, long-term follow
\end{abstract}

\section{Introduction}

Guillain-Barré syndrome (GBS) is a rare and serious autoimmune disorder of peripheral nerves. A number of subtypes of GBS are recognized: acute inflammatory demyelinating polyradiculoneuropathy (the most common form marked by an areflexive muscular weakness evolving subacutely), Miller Fisher syndrome, acute motor axonal neuropathy, and acute motor-sensory axonal neuropathy. ${ }^{1,2}$ Fulminant cases of GBS have been reported in which a rapid clinical deterioration can mimic brain death. This clinical presentation is very rare, and disease diagnosis can be challenging.

\section{Case presentation}

Mr. X, a 47-year-old Caucasian male patient with no medical history visited the emergency unit on July 17, 2007 because of diplopia and dysphonia that had appeared during the night. On admission, the Glasgow coma scale score was 15/15, hemodynamics were preserved, and body temperature was $37.4^{\circ} \mathrm{C}$. Medical history showed that the patient had diarrhea that lasted for one week, without improvement even after 5 days of symptomatic treatment. There was no report of recent vaccinations or travel. Clinical examination showed diplopia and dysphonia with nasal speech. He did not present any muscular weakness or sensory loss, and osteotendinous reflexes were present and symmetrical. Cranial nerve examination did not show swallowing disorder, oculomotor 
disorder, or facial paralysis. The patient had no difficulty in walking, no pain or amyotrophy, no sphincter disorder, and no cauda equina syndrome. The plantar reflex was in flexion.

Laboratory tests were also normal. A brain CT with and without contrast was unremarkable. Lumbar puncture showed a clear cerebrospinal fluid with normal leukocyte count (less than $5 / \mathrm{mm}^{3}$ cells), proteins $44 \mathrm{mg} / \mathrm{dL}$ (normal range $20-40 \mathrm{mg} / \mathrm{dL})$, glucose $61 \mathrm{mg} / \mathrm{dL}(\mathrm{n}=45-80)$, and chloride $123 \mathrm{mEq} / \mathrm{L}$ ( $\mathrm{n}=116-127)$. Cerebrospinal fluid culture remained negative after 2 days.

Yet, 3 hours after admission, became marked impairing speech, and paresthesia and numbness of the tongue was observed. Mr. X also reported paresthesia in his hands, without motor deficit. A Doppler ultrasound of carotid and vertebral arteries was unremarkable. While awaiting the results of bacteriological and viral testing, an empirical antibiotic treatment with amoxicillin, acyclovir, and sulfamethoxazole-trimethoprime was started in the eventuality of meningitis or meningoencephalitis.

A Guillain-Barré syndrome was suspected, and so the patient was transferred to the medical intensive care unit. On admission to the intensive care unit, the patient was conscious and had a Glasgow coma scale score of 15/15. There was persistent dysphonia and impaired swallowing and vision; otherwise, the neurological examination was unchanged. Invasive ventilation was initiated soon after.

Antibiotic therapy was switched to amoxicillin-clavulanic acid for one week in view of suspected aspiration pneumonia. Intravenous immunoglobulin (IVIG) therapy was started on admission at $0.4 \mathrm{~g} / \mathrm{kg}$ a day for 5 days. Sedation (midazolam and remifentanil) was stopped on day 1 ; on day 3 , the patient showed no sign of awakening. The Glasgow coma scale score was 3 . The pupils were in nonreactive bilateral mydriasis.

\section{Investigations and treatment}

A second lumbar puncture was performed on day 2; cerebrospinal fluid was clear with less than 5 cells $/ \mathrm{mm}^{3}$ and showed slightly elevated protein level at $89 \mathrm{mg} / \mathrm{dL}$ and normal glucose at $74 \mathrm{mg} / \mathrm{dL}$ and chloride at $123 \mathrm{mEq} / \mathrm{L}$. There were no microorganisms identified. A brain magnetic resonance imaging showed no evidence of ischemic lesion or tumor. On electromyogram, a segmental and focal demyelination with a complete conduction block was seen, but this did not explain the impairment of consciousness. Electroencephalogram trace was compatible with paradoxical sleep. The suspected diagnosis was fulminant GBS. Auditory evoked potentials were not contributory, giving evidence of a hearing loss to below 60 decibels. The diagnostic serology for Campylobacter jejuni (C. jejuni) was positive, with an antibody IgM isotype titer of 1:320 determined by ELISA (positivity threshold value at 1:20). Further investigations ruled out the presence of the following: botulinum toxins, Campylobacter fetus, listeriosis, HBV, HCV, HIV, EBV, HSV, CMV, syphilis, Borrelia.

A percutaneous tracheostomy was rapidly performed. Because of the lack of neurological improvement over several weeks, a second course of IVIG was given. At the end of the course, there was a slight clinical improvement as the patient could move the toes on both feet in response to simple commands. A third course of IVIG was given. Progress was marked by slight movements of the head and few movements of both eyelids. Mr. X benefited from four plasma exchanges and a fourth course of IVIG. With regard to muscular power, a strengthening of the upper and lower girdles was noted, with a result of $1 / 5$ on motor testing. However, there was a persistent tetraplegia. With regard to sensitivity, a subjective improvement in the sensibility of the forearms and the back were noted. As Mr. X developed a severe reactional depressive syndrome, he was given an antidepressant treatment along with psychological treatment during his hospitalization. It should be noted that the patient had pain in the right hip for several weeks, a scan showed periarthritis of neurogenic origin. Breathing status improved slowly, enabling spontaneous breathing for a few hours per day at 3 months, with mechanical ventilation at night. The progress was marked by three episodes of ventilator-associated pneumonia.

\section{Outcome and follow-up}

The patient was transferred to a rehabilitation center 4 months after his initial admission to the hospital. Rehabilitation was slow despite daily physiotherapy combined with activities involving an occupational therapist and psychomotility therapist. After an essentially passive mobilization phase designed to maintain the trophicity and mobility of the joints, the patient was able to spend prolonged periods in a chair at 8 months and began to get about in a wheelchair at 9 months. Otherwise, full weaning from ventilation and final cannula removal took place at 10 months. Readaptation to orthostatism was progressive, and then rehabilitation in a swimming pool at 12 months facilitated active mobilization. At the same time, motor work and sensory and proprioceptive stimulation were essential. The patient was discharged home one year later with continuation of rehabilitation sessions for 2 years. After requiring the use of an electric wheelchair and then a manual one, he was able to stand up again after two years, in March 2009, and was able to walk by June 2009.

Currently, muscular weakness persists, grade 3-4/5, with regard to flexion and extension. On a functional level, 
Mr. X walks with 2 crutches with a forearm support and is still dependent in his day-to-day life, requiring assistance with washing and dressing, but he goes alone to the swimming baths, rides an electric tricycle outside, and drives an adapted automatic car with a special license. He no longer has dysphonia or slight difficulty swallowing. No significant improvement in muscular strength has been noted for the last 3 years.

\section{Discussion}

Guillain-Barré syndrome in its fulminant form is very rare. The strength of our case is in the long-term follow-up, both in terms of quality of life and recovery long after the initial hospitalization, as 9 years have now passed since the acute phase. The patient is still severely disabled in spite of physiotherapy. His private, social, and professional life has been shattered. We believe this is the only paper detailing such a long-term follow-up of a fulminant GBS case.

Thirty-four cases have been previously described in the literature (Table 1). Diagnosis can be very difficult when the patient is seen during the coma period with no previous case history. On day 3, our patient's Glasgow coma scale score was $3 / 15$ and there was a nonreactive bilateral mydriasis. The presence of bilateral mydriasis has rarely been described in GBS. ${ }^{3}$ This finding can be explained by a demyelination of the synaptic and parasympathetic preganglionic fibers that supply the pupil. ${ }^{4}$ However, pupillary involvement is common in Miller Fischer syndrome, a variant of GBS, and mydriasis has also been reported in more than a third of Miller Fischer syndrome patients. ${ }^{5}$ Polyneuropathy is sometimes absent from the initial clinical picture. ${ }^{4}$ The outcome of lumbar puncture

Table I Clinical characteristics

\begin{tabular}{|c|c|c|c|c|c|}
\hline Study & Age/Sex & Patterns of deficit & History & Pathogen & $\begin{array}{l}\text { Time to } \\
\text { nadir (days) }\end{array}$ \\
\hline Carroll and Mastaglia, ${ }^{24} 1979$ & $45 / M$ & Generalized tetraparesis & Rhinopharyngitis & & 5 \\
\hline Kotsoris et al, ${ }^{25} 1984$ & $44 / M$ & Generalized ascending tetraparesis & NR & & 2 \\
\hline Al-din et al, ${ }^{26} 1985$ & $45 / M$ & NR & NR & & 3 \\
\hline Drury et al, ${ }^{6} 1987$ & $63 / M$ & Generalized tetraparesis & Rhinopharyngitis & & 2 \\
\hline Kanda et al, ${ }^{9} 1989$ & $47 / M$ & Generalized ascending tetraparesis & Rhinopharyngitis & & 6 \\
\hline Coad and Byrne, 271990 & $43 / M$ & Diplopia followed by generalized tetraparesis & Rhinopharyngitis & & 4 \\
\hline Hassan and Mumford, ${ }^{28} 1991$ & $45 / M$ & Muscle weakness, diplopia & Diarrhea & & 3 \\
\hline Fuller et $\mathrm{al}^{3}{ }^{3} \mathrm{I} 992$ & $63 / M$ & Generalized tetraparesis & NR & & 2 \\
\hline Marti-Masso et al, ${ }^{22} 1993$ & $58 / F$ & Dysphonia followed by generalized tetraparesis & NR & & 2 \\
\hline Tan and Chee, ${ }^{7} 1995$ & $50 / F$ & $\begin{array}{l}\text { Muscle weakness followed by generalized } \\
\text { tetraparesis }\end{array}$ & Diarrhea & & 2 \\
\hline Bakshi et al, ${ }^{8} 1997$ & $6 / M$ & Generalized tetraparesis & Diarrhea & & 2 \\
\hline Berciano et al, ${ }^{10} 1997$ & $67 / M$ & Dyspnea followed by generalized tetraparesis & Diarrhea & C. jejunii & 2 \\
\hline Bohlega et al, ${ }^{17} 1997$ & $45 / M$ & Generalized ascending tetraparesis & NR & & 3 \\
\hline Hughes and McGuire, ${ }^{29} 1997$ & $27 / M$ & $\begin{array}{l}\text { Difficulty swallowing followed by generalized } \\
\text { tetraparesis }\end{array}$ & Rhinopharyngitis & & 5 \\
\hline Thomas, ${ }^{30} 2000$ & $36 / M$ & Generalized ascending tetraparesis & Rhinopharyngitis & & 2 \\
\hline Vargas et al, ${ }^{4} 2000$ & $45 / F$ & Generalized tetraparesis & Rhinopharyngitis & & 1 \\
\hline Ragazzoni et al, ${ }^{3 \prime} 2000$ & $40 / M$ & Generalized ascending tetraparesis & Rhinopharyngitis & & 2 \\
\hline Stojkovic et al, ${ }^{32} 200 \mathrm{I}$ & & Generalized tetraparesis & Cranial trauma & & 2 \\
\hline Saito, ${ }^{12} 2002$ & $21 / M$ & Dysarthria & Diarrhea & C. jejunii & 4 \\
\hline Friedman et al," 2003 & $57 / F$ & Distal paresthesias in lower limbs & NR & & 6 \\
\hline Friedman et al,"' 2003 & $27 / M$ & Diplopia, difficulty swallowing then tetraparesis & Cranial trauma & C. jejunii & 3 \\
\hline Moussouttas et al, ${ }^{33} 2004$ & $47 / F$ & Distal paresthesias in lower limbs & Cranial trauma & & 5 \\
\hline Kang and Kim, ${ }^{21} 2007$ & $32 / M$ & Distal paresthesias in lower limbs, facial diplegia & Diarrhea & Hepatitis A & 4 \\
\hline Tagami et al, ${ }^{34} 2008$ & $65 / M$ & NR & NR & H. influenzae & NR \\
\hline Rivas et al, ${ }^{35} 2008$ & $55 / M$ & Generalized tetraparesis & Cranial trauma & & 7 \\
\hline Joshi et al, ${ }^{36} 2008$ & $34 / M$ & Generalized tetraparesis & NR & & 2 \\
\hline Joshi et al, ${ }^{36} 2008$ & $59 / M$ & Generalized ascending tetraparesis & NR & & 10 \\
\hline Rigamonti et al, ${ }^{37} 2009$ & $6 I / F$ & Muscle weakness followed by tetraparesis & Diarrhea & & I \\
\hline Tan et $a l,{ }^{38} 2010$ & $44 / M$ & Distal paresthesias in lower limbs & Cranial trauma & & 2 \\
\hline Bernard et al, ${ }^{39} 2010$ & $73 / F$ & NR & NR & & NR \\
\hline Sevketoglu et al, ${ }^{40} 2010$ & $5 / M$ & Dysphonia, difficulty swallowing & NR & & 1 \\
\hline Medici et al, ${ }^{41} 201 \mathrm{I}$ & $5 / M$ & Dysarthria, facial diplegia & NR & & I \\
\hline Medici et al, ${ }^{41} 201 \mathrm{I}$ & 3 months/M & Facial diplegia & $\begin{array}{l}\text { Tetanus-diphtheria } \\
\text { vaccination }\end{array}$ & & 1 \\
\hline Medici et al, ${ }^{41} 2011$ & $8 / M$ & Diplopia, dysarthria, tetraparesis & Diarrhea & & I \\
\hline
\end{tabular}

Abbreviation: NR, not reported. 
and the investigations are therefore all-important in this case. ${ }^{6,7}$ In some patients, a pathological analysis with nerve biopsy has been performed. ${ }^{3,8-10}$ One common characteristic of the various reported cases is the rapid onset of "pseudo-coma," occuring on average 3 days from first symptoms. Electrophysiological studies have shown 18 cases with demyelination and 11 cases with axonal involvement (Table 2).

Moreover, three cases of fulminant GBS with antecedent C. jejuni infection have been reported. ${ }^{10-12}$ C. jejuni is the pathogenic agent most commonly found in cases of GBS preceded by diarrhea. Since the first cases described in 1982, the severity of GBS following infection with $C$. jejuni has been evidenced and includes frequent axonal involvement, slower recovery, and more severe disability. ${ }^{13,14}$

Reported treatments were not homogeneous, and it is therefore impossible to establish a consensus. They are described in Table 3 but are not mentioned in every study. However, it is important to emphasize that repeated courses of IVIG may be effective in severe, unresponsive GBS. ${ }^{15}$ Our patient received four courses of IVIG and four plasma exchanges.

Publications including long-term data after fulminant GBS are very sparse in the literature, and so it is difficult to reach a conclusion on this point. However, recovery of neurological function in fulminant GBS seems to be poor, and the disease

Table 2 Paraclinical characteristics

\begin{tabular}{|c|c|c|c|c|c|}
\hline Study & $\begin{array}{l}\text { Lumbar } \\
\text { puncture }\end{array}$ & $\begin{array}{l}\text { Protein concentration } \\
(\mathrm{mg} / \mathrm{dL})\end{array}$ & NCS & EEG & Biopsy \\
\hline Carroll and Mastaglia, ${ }^{24} 1979$ & Dissociation & 42 & & Alpha & \\
\hline Kotsoris et al, ${ }^{25} 1984$ & Dissociation & 462 & Inexcitability & Alpha & \\
\hline Drury et al, ${ }^{6} 1987$ & Dissociation & 58 & Inexcitability & Alpha reactive & \\
\hline Kanda et al, ${ }^{9} 1989$ & Dissociation & 58 & & & Demyelination \\
\hline Coad and Byrne, ${ }^{27} 1990$ & Dissociation & 200 & Inexcitability & Alpha & \\
\hline Hassan and Mumford, ${ }^{28} 1991$ & Normal & 25 & Inexcitability & Alpha reactive & \\
\hline Fuller et al, ${ }^{3} 1992$ & Dissociation & 75 & Inexcitability & $\begin{array}{l}\text { Alpha waves and } \\
\text { diffuse beta activity }\end{array}$ & $\begin{array}{l}\text { Primary demyelination, } \\
\text { axonal degeneration }\end{array}$ \\
\hline Marti-Masso et al, ${ }^{22} 1993$ & Dissociation & 75 & Axonopathy & Alpha nonreactive & \\
\hline Tan and Chee, ${ }^{7} 1995$ & Normal & 20 & Inexcitability & Alpha reactive & \\
\hline Bakshi et al, ${ }^{8} 1997$ & Dissociation & 167 & Inexcitability & $\begin{array}{l}\text { Reactive theta } \\
\text { activity, sleep }\end{array}$ & Demyelination \\
\hline Berciano et al, ${ }^{10} 1997$ & Pleocytosis & 198 & Inexcitability & Alpha reactive & $\begin{array}{l}\text { Primary demyelination, } \\
\text { axonal degeneration }\end{array}$ \\
\hline Bohlega et al, ${ }^{17} 1997$ & Dissociation & 605 & Inexcitability & & $\begin{array}{l}\text { Primary demyelination, } \\
\text { axonal degeneration }\end{array}$ \\
\hline Hughes and McGuire, ${ }^{29} 1997$ & Dissociation & 58 & $\begin{array}{l}\text { Demyelination with } \\
\text { axonal loss }\end{array}$ & Sleep & $\begin{array}{l}\text { Primary demyelination, } \\
\text { axonal degeneration }\end{array}$ \\
\hline Vargas et al, ${ }^{4} 2000$ & Dissociation & 90 & Inexcitability & Alpha & $\begin{array}{l}\text { Primary demyelination, } \\
\text { axonal degeneration }\end{array}$ \\
\hline Ragazzoni et al, 2000 & Dissociation & 70 & Inexcitability & Reactive & \\
\hline Stojkovic et al, ${ }^{32} 2001$ & & 197 & Demyelination & & \\
\hline Saito, ${ }^{12} 2002$ & & 65 & Axonopathy & & \\
\hline Friedman et al," 2003 & Dissociation & & Inexcitability & Theta & Axonal degeneration \\
\hline Friedman et al," 2003 & Dissociation & 58 & Axonopathy & Alpha reactive & \\
\hline Moussouttas et al, ${ }^{33} 2004$ & Dissociation & & Inexcitability & Nonspecific slowing & \\
\hline Kang and Kim, ${ }^{21} 2007$ & Dissociation & 115 & Axonopathy & Alpha & \\
\hline Rivas et al, ${ }^{35} 2008$ & Dissociation & & Inexcitability & Alpha & Axonal degeneration \\
\hline Joshi et al, ${ }^{36} 2008$ & Dissociation & & Inexcitability & $\begin{array}{l}\text { Nonspecific slowing } \\
\text { reactive }\end{array}$ & \\
\hline Joshi et al, ${ }^{36} 2008$ & & & Inexcitability & $\begin{array}{l}\text { Nonspecific slowing } \\
\text { reactive }\end{array}$ & \\
\hline Rigamonti et al, ${ }^{37} 2009$ & Dissociation & 85 & Inexcitability & Nonspecific slowing & \\
\hline Tan et al, ${ }^{38} 2010$ & Dissociation & 182 & & & Macrophages \\
\hline Bernard et al, ${ }^{39} 2010$ & Dissociation & & Axonopathy & $\begin{array}{l}\text { Nonspecific slowing } \\
\text { reactive }\end{array}$ & \\
\hline Sevketoglu et al, ${ }^{40} 2010$ & Dissociation & 70 & Axonopathy & & \\
\hline Medici et al, ${ }^{41} 201 \mathrm{I}$ & Dissociation & 117 & Axonopathy & & \\
\hline Medici et al, ${ }^{4 \mid} 201 \mathrm{I}$ & Dissociation & 260 & Axonopathy & & \\
\hline Medici et al, ${ }^{4 \mid} 201 \mathrm{I}$ & Dissociation & 180 & Axonopathy & & \\
\hline
\end{tabular}

Abbreviations: NCS, nerve conduction study; EEG, electroencephalogram. 
has a high mortality rate. Outcomes for patients affected with fulminant GBS are described in Table 3. Absence of excitability on EMG and dependency on mechanical ventilation for more than one month are factors indicative of poor prognosis. ${ }^{16}$ Fulminant GBS has a more serious prognosis than "standard" GBS. ${ }^{17}$ Indeed, our literature review found $5 / 34$ deaths $(14.7 \%)$ and $52 \%$ severely disabled patients, as opposed to the lower reported rates of death and disability in "standard" GBS (4\% and 14\% respectively). ${ }^{18}$ It is worth noting that the majority of deaths in the cohort took place

Table 3 Treatments and outcomes

\begin{tabular}{|c|c|c|c|c|c|c|}
\hline Study & Treatment & Dysautonomia & $\begin{array}{l}\text { “Brain } \\
\text { death" (days) }\end{array}$ & Mortality & Other & Outcome \\
\hline Carroll and Mastaglia, ${ }^{24} 1979$ & & & & & Amnesia & Walks with assistance (crutches) \\
\hline Kotsoris et al, ${ }^{25} 1984$ & & & 6 & & & $\begin{array}{l}\text { Handicapped, partial motor } \\
\text { recovery }\end{array}$ \\
\hline Al-din et al, ${ }^{26} 1985$ & & & 5 & & & $\begin{array}{l}\text { Severe weakness (after } 3 \\
\text { months) }\end{array}$ \\
\hline Drury et al, ${ }^{6} 1987$ & & & 46 & & Amnesia & \\
\hline Kanda et al, ${ }^{9} 1989$ & PE & $\mathrm{CA}$ & 7 (death) & CA day 5 & & \\
\hline Coad and Byrne, ${ }^{27} 1990$ & & & 5 & & & Complete gradual recovery \\
\hline Hassan and Mumford, ${ }^{28} 1991$ & & & & & & $\begin{array}{l}6 \text { months of mechanical } \\
\text { ventilation, wheelchair }\end{array}$ \\
\hline Fuller et al, ${ }^{3} 1992$ & PE/corticosteroids & Arrythmia, CA & 7 & CA day 28 & & \\
\hline Marti-Masso et al, ${ }^{22} 1993$ & $\mathrm{PE}(6)$ & Arrythmia & 13 & & Amnesia & Can walk unaided after I year \\
\hline Tan and Chee, ${ }^{7} 1995$ & Gamma globulin & & 12 & Day 98 & Amnesia & $\begin{array}{l}\text { Significant sequelae after } 2 \\
\text { months }\end{array}$ \\
\hline Bakshi et al, ${ }^{8} 1997$ & Gamma globulin & & "Few weeks" & & & $\begin{array}{l}\text { Significant sequelae, walks with } \\
\text { assistance after I year }\end{array}$ \\
\hline Berciano et al, ${ }^{10} 1997$ & PE/corticosteroids & CA & & CA day 18 & & \\
\hline Bohlega et al, ${ }^{17} 1997$ & PE/gamma globulin & & 31 & & & $\begin{array}{l}\text { Severe handicap, proximal } \\
\text { recovery after } 30 \text { months }\end{array}$ \\
\hline Hughes and McGuire, ${ }^{29} 1997$ & Gamma globulin & & & & & $\begin{array}{l}\text { Significant sequelae after } 6 \\
\text { months }\end{array}$ \\
\hline Vargas et al, ${ }^{4} 2000$ & PE & & & & & Severe handicap \\
\hline Ragazzoni et al," 2000 & PE & & & & Amnesia & \\
\hline Stojkovic et al, ${ }^{32} 200 \mathrm{l}$ & Gamma globulin & & & & & \\
\hline Saito, ${ }^{12} 2002$ & $\begin{array}{l}\text { PE/Gamma } \\
\text { globulin(2) }\end{array}$ & Tachycardia & & & & $\begin{array}{l}\text { Significant sequelae } \\
\text { predominantly in lower limbs }\end{array}$ \\
\hline Friedman et al," 2003 & & & 16 & & & $\begin{array}{l}4 / 5 \text { Motor sequelae in upper } \\
\text { limbs, } 3 / 5 \text { in lower limbs }\end{array}$ \\
\hline Friedman et al," 2003 & Gamma globulin & & & & Amnesia & $\begin{array}{l}\text { Partial proximal recovery, } 3 / 5 \text { in } \\
\text { lower limbs }\end{array}$ \\
\hline Moussouttas et al, ${ }^{33} 2004$ & $\mathrm{PE}$ /gamma globulin & & & & & Complete recovery \\
\hline Kang and Kim, ${ }^{21} 2007$ & $\begin{array}{l}\text { Gamma globulin/ } \\
\text { corticosteroids }\end{array}$ & Bradycardia & & & & $\begin{array}{l}\text { Good recovery and ability to } \\
\text { walk }\end{array}$ \\
\hline Tagami et al, ${ }^{34} 2008$ & $\mathrm{PE}$ /gamma globulin & & & & Depression & Major sequelae \\
\hline Rivas et al, ${ }^{35} 2008$ & & & & & & Handicapped \\
\hline Joshi et al, ${ }^{36} 2008$ & & & & & & Handicapped \\
\hline Joshi et al, ${ }^{36} 2008$ & & & & & & Handicapped \\
\hline Rigamonti et al, ${ }^{37} 2009$ & Gamma globulin & Tachycardia & 15 & & & Walks with assistance (crutches) \\
\hline Tan et al, ${ }^{38} 2010$ & Gamma globulin(2) & $\begin{array}{l}\text { Blood pressure } \\
\text { lability }\end{array}$ & & & & \\
\hline Bernard et al, ${ }^{39} 2010$ & Gamma globulin & & 12 & $\begin{array}{l}\text { Septic } \\
\text { shock day } \\
\text { I } 58\end{array}$ & & \\
\hline Sevketoglu et al, ${ }^{40} 2010$ & PE/gamma globulin(2) & & & & & Partial motor recovery \\
\hline Medici et al, ${ }^{41} 2011$ & $\begin{array}{l}\text { PE/gamma globulin/ } \\
\text { corticosteroids }\end{array}$ & & 7 & & & Complete recovery \\
\hline Medici et al, ${ }^{41} 201 \mathrm{I}$ & Gamma globulin & & 15 & & & Handicapped, partial recovery \\
\hline Medici et al, ${ }^{41} 201 \mathrm{I}$ & Gamma globulin & & 5 & & & \\
\hline
\end{tabular}

Abbreviations: $\mathrm{PE}$, plasma exchange; $\mathrm{CA}$, cardiac arrest. 
before 2000, (4/5) with dysautonomic complications being more frequent during this period. After the acute phase, GBS patients have both physical and cognitive disabilities that are amenable to improvement with rehabilitation programs focusing on specific complications (ie, therapeutic exercises avoiding overexertion for weakness, soaking techniques for sensory loss, transcutaneous electrical nerve stimulation for residual pain, biofeedback techniques for neurologic bladder and bowel). ${ }^{19}$ Moreover, rehabilitation of highly dependent GBS patients results in significant reduction in ongoing care costs and is cost-efficient despite significant residual disability. ${ }^{20}$

When electrophysiological investigations are available, fulminant GBS is more likely to be accompanied by axonal damage ( $50 \%$ in our cohort), a feature associated with slower and less satisfactory functional recovery. ${ }^{11,17} \mathrm{Clinical}$ cases for which a sural biopsy was carried out showed that axonal damage was preceded by a phase of severe distal demyelination with conduction blocks. ${ }^{21}$ Electroencephalogram (EEG) tracings typically identify alpha rhythm activity unresponsive to painful and auditory stimulation during fulminant GBS, but other tracings have also been reported (sleep, responsive or the so-called "alpha-delta" stage of sleep). ${ }^{4}$ Continuous EEG monitoring could be of particular interest in this setting to assess variability in EEG pattern over hours or days as opposed to minutes. Unfortunately, this procedure was not yet available in our institution.

The patient has recovered his cognitive functions but has no memory of the acute phase, as is commonly described in previously published cases. ${ }^{22}$ GBS can also be complicated by a reactive depressive syndrome. ${ }^{2,23}$ Our patient developed a depressive state, thus requiring specialist management with long-term antidepressant treatment.

\section{Conclusion}

Fulminant GBS with brain-death presentation is rare but deserves medical knowledge and awareness. Its diagnosis leads to a well-established treatment that reduces long-term disability. This case reminds us of the importance of electrophysiological investigations during clinical brain-death states with no definite cause. Finally, long-term physiotherapy and specific rehabilitation programs appear essential to improve recovery.

\section{Consent}

Written informed consent was obtained from the patient for publication of this case report.

\section{Author contributions}

AR collected data and wrote the manuscript, JL helped to collect data, obtained patient's consent, and reviewed the manuscript,
SG participated in design and coordination of the manuscript, PEB conceived and coordinated the study. All authors contributed toward data analysis, drafting and critically revising the paper and agree to be accountable for all aspects of the work.

\section{Acknowledgments}

We gratefully acknowledge the valuable contribution of the Department of Intensive Care Unit and Neurology of the CHU of Nancy, and the Faculty of Medicine of Nancy.

\section{Disclosure}

The authors report no conflicts of interest in this work.

\section{References}

1. Hughes RA, Cornblath DR. Guillain-Barré syndrome. Lancet. 2005; 366(9497):1653-1666.

2. Bernsen RA, de Jager AE, Schmitz PI, van der Meché FG. Long-term impact on work and private life after Guillain-Barré syndrome. JNeurol Sci. 2002;201(1-2):13-17.

3. Fuller GN, Jacobs JM, Lewis PD, Lane RJ. Pseudoaxonal GuillainBarré syndrome: severe demyelination mimicking axonopathy. A case with pupillary involvement. J Neurol Neurosurg Psychiatry. 1992;55(11):1079-1083.

4. Vargas F, Hilbert G, Gruson D, Valentino R, Gbikpi-Benissan G, Cardinaud JP. Fulminant Guillain-Barré syndrome mimicking cerebral death: case report and literature review. Intensive Care Med. 2000;26:623-627.

5. Mori M, Kuwabara S, Fukutake T, Yuki N, Hattori T. Clinical features and prognosis of Miller Fisher syndrome. Neurology. 2001;56(8):1104-1106.

6. Drury I, Westmoreland BF, Sharbrough FW. Fulminant demyelinating polyradiculoneuropathy resembling brain death. Electroencephalogr Clin Neurophysiol. 1987;67(1):42-43.

7. Tan AK, Chee MW. Fulminant Guillain-Barré syndrome with quadriplegia and total paresis of motor cranial nerves as a result of segmental demyelination. J Neurol Sci. 1995;134(1-2):203-206.

8. Bakshi N, Maselli RA, Gospe SM, Ellis WG, McDonald C, Mandler RN. Fulminant demyelinating neuropathy mimicking cerebral death. Muscle Nerve. 1997;20(12):1595-1597.

9. Kanda T, Hayashi H, Tanabe H, Tsubaki T, Oda M. A fulminant case of Guillain-Barré syndrome: topographic and fiber size related analysis of demyelinating changes. J Neurol Neurosurg Psychiatry. 1989;52(7): 857-864.

10. Berciano J, Figols J, García A, et al. Fulminant Guillain-Barré syndrome with universal inexcitability of peripheral nerves: a clinicopathological study. Muscle Nerve. 1997;20(7):846-857.

11. Friedman Y, Lee L, Wherrett JR, Ashby P, Carpenter S. Simulation of brain death from fulminant de-efferentation. Can J Neurol Sci J (Can Sci Neurol). 2003;30(4):397-404.

12. Saito T. Fulminant Guillain-Barré syndrome after Campylobacter jejuni enteritis and anti-ganglioside antibody. Intern Med. 2002;41(10):760-761.

13. Rhodes KM, Tattersfield AE. Guillain-Barre syndrome associated with Campylobacter infection. Br Med JClin Res Ed. 1982;285(6336):173-174.

14. Rees JH, Soudain SE, Gregson NA, Hughes RA. Campylobacter jejuni infection and Guillain-Barré syndrome. NEngl JMed. 1995;333(21):1374-1379.

15. Farcas P, Avnun L, Frisher S, Herishanu YO, Wirguin I. Efficacy of repeated intravenous immunoglobulin in severe unresponsive GuillainBarré syndrome. Lancet. 1997;350(9093):1747.

16. Winer JB, Hughes RA, Greenwood RJ, Perkin GD, Healy MJ. Prognosis in Guillain-Barré syndrome. Lancet. 1985;1(8439):1202-1203.

17. Bohlega SA, Stigsby B, Haider A, McLean D. Guillain-Barré syndrome with severe demyelination mimicking axonopathy. Muscle Nerve. 1997;20(4):514-516.

18. Rajabally YA, Uncini A. Outcome and its predictors in Guillain-Barre syndrome. J Neurol Neurosurg Psychiatry. 2012;83(7):711-718. 
19. Orsini M, De Freitas M, Presto B, et al. Guideline for neuromuscular rehabilitation in Guillain-Barré syndrome: what can we do. Rev Neurocienc. 2010;18(4):572-580.

20. Alexandrescu R, Siegert RJ, Turner-Stokes L. Functional Outcomes and Efficiency of Rehabilitation in a National Cohort of Patients with Guillain - Barré Syndrome and Other Inflammatory Polyneuropathies. PLoS ONE, 2014:9. Available from: http://www.ncbi.nlm.nih.gov/pmc/ articles/PMC4234218/. Accessed November 17, 2014.

21. Kang BH, Kim KK. Fulminant guillain-barré syndrome mimicking cerebral death following acute viral hepatitis a. J Clin Neurol. 2007; 3(2):105-107.

22. Martí-Massó JF, Suárez J, López de Munain A, Carrera N. Clinical signs of brain death simulated by Guillain-Barré syndrome. J Neurol Sci. 1993; 120(1):115-117.

23. Liik M, Puksa L, Lüüs S-M, Haldre S, Taba P. Fulminant inflammatory neuropathy mimicking cerebral death. BMJ Case Rep. 2012; 2012:bcr1020114906.

24. Carroll WM, Mastaglia FL. "Locked-in coma" in postinfective polyneuropathy. Arch Neurol. 1979;36(1):46-47.

25. Kotsoris H, Schliefer L, Menken M, Plum F. Total locked-in state resembling brain death in polyneuropathy. Ann Neurol. 1984;16:150.

26. Al-Din AS, Jamil AS, Shakir R. Coma and brain stem areflexia in brain stem encephalitis (Fisher's syndrome). Br Med J (Clin Res Ed). 1985; 291(6494):535-536.

27. Coad NR, Byrne AJ. Guillain-Barré syndrome mimicking brainstem death. Anesthesia. 1990;45(6):456-457.

28. Hassan T, Mumford C. Guillain-Barré syndrome mistaken for brain stem death. Postgrad Med J. 1991;67(785):280-281.

29. Hughes R, McGuire G. Neurologic disease and the determination of brain death: the importance of a diagnosis. Crit Care Med. 1997; 25(11):1923-1924.

30. Thomas PD. The differential diagnosis of fixed dilated pupils: a case report and review. Crit Care Resusc. 2000;2(1):34-37.
31. Ragazzoni A, Grippo A, Tozzi F, Zaccara G. Event-related potentials in patients with total locked-in state due to fulminant Guillain-Barré syndrome. Int J Psychophysiol. 2000;37(1):99-109.

32. Stojkovic T, Verdin M, Hurtevent JF, Laureau E, Krivosic-Horber R, Vermersch P. Guillain-Barré syndrome resembling brainstem death in a patient with brain injury. J Neurol. 2001;248(5):430-432.

33. Moussouttas M, Chandy D, Dyro F. Fulminant acute inflammatory demyelinating polyradiculoneuropathy: case report and literature review. Neurocrit Care. 2004;1(4):469-473.

34. Tagami S, Susuki K, Takeda M, Koga M. Fulminant case of GuillainBarré syndrome with poor recovery and depression following Haemophilus influenzae infection. Psychiatry Clin Neurosci. 2008;62(4):486.

35. Rivas S, Douds GL, Ostdahl RH, Harbaugh KS. Fulminant GuillainBarré syndrome after closed head injury: a potentially reversible cause of an ominous examination. Case report. J Neurosurg. 2008;108(3): 595-600.

36. Joshi MC, Azim A, Gupta GL, Poddar BP, Baronia AK, Singh RK. Guillain-Barré syndrome with absent brainstem reflexes - a report of two cases. Anaesth Intensive Care. 2008;36(6):867-869.

37. Rigamonti A, Basso F, Stanzani L, Agostoni E, Lauria G. Guillain-Barré syndrome mimicking brain death. J Peripher Nerv Syst. 2009;14(4): 316-319.

38. Tan IL, Ng T, Vucic S. Severe Guillain-Barré syndrome following head trauma. J Clin Neurosci. 2010;17(11):1452-1454.

39. Bernard V, Van Pesch V, Hantson P. Guillain-Barré syndrome mimicking brain death pattern: a poorly reversible condition. Acta Neurol Belg. 2010;110(1):93-96.

40. Sevketoglu E, Tatlı B, Tu-cu B, Demirelli Y, Hatipoglu S. An unusual cause of fulminant Guillain-Barré syndrome: angel's trumpet. Pediatr Neurol. 2010;43(5):368-370.

41. Medici C, Gonzalez G, Cerisola A, Scavone C. Locked-in syndrome in three children with Guillain-Barré syndrome. Pediatr Neurol. 2011;45(2): $125-128$.
International Medical Case Reports Journal

\section{Publish your work in this journal}

The International Medical Case Reports Journal is an international, peer-reviewed open-access journal publishing original case reports from all medical specialties. Previously unpublished medical posters are also accepted relating to any area of clinical or preclinical science. Submissions should not normally exceed 2,000 words or

\section{Dovepress}

4 published pages including figures, diagrams and references. The manuscript management system is completely online and includes a very quick and fair peer-review system, which is all easy to use. Visit http://www.dovepress.com/testimonials.php to read real quotes from published authors. 